\title{
Interaction of nanoparticles with arginine kinase from Trypanosoma brucei: Kinetic and mechanistic evaluation
}

\author{
Oluyomi Stephen Adeyemi, Chris George Whiteley* \\ Department of Biochemistry, Microbiology \& Biotechnology Rhodes University, Grahamstown, South Africa
}

\section{A R T I C L E I N F O}

\section{Article history:}

Received 10 July 2013

Received in revised form

13 September 2013

Accepted 13 September 2013

Available online 26 September 2013

\section{Keywords:}

Trypanosomiasis

Arginine kinase

Silver, gold nanoparticles

Kinetic analysis

Mechanism

\begin{abstract}
A B S T R A C T
Arginine kinase is not only absent from mammalian hosts but is critical to the survival of trypanosomes under stressful conditions and consequently its inhibition may lead to an effective treatment for trypanosomiasis. The His-tagged enzyme was cloned from Trypanosoma brucei genomic DNA, expressed in Escherichia coli BL21 DE3 cells and purified on a Ni-affinity column and by FPLC on a Superdex $200 \mathrm{HR}$. The enzyme had a specific activity of $2.92 \mu \mathrm{mol} \mathrm{min}^{-1} \mathrm{mg}$ protein ${ }^{-1}$, molecular mass of $40 \mathrm{kDa}$, temperature and pH optima of $30^{\circ} \mathrm{C}$ and 7.8 , and $K_{m}$ and $V_{\max }$ as $2.94 \mathrm{mM}$ and $0.161 \mu \mathrm{mol} \mathrm{ml}^{-1} \mathrm{~min}^{-1}$ (arginine substrate). The interaction of the enzyme with silver and gold nanoparticles showed a non-competitive inhibition with, respectively, $75 \%$ and $62 \%$ decrease in activity; $K_{\mathrm{i}}$ values ranged from $1.5 \mathrm{nM}(\mathrm{Ag})$ to $3.1 \mathrm{nM}(\mathrm{Au})$. A mechanism for this inhibition was by interaction with $\mathrm{Cys}^{271}$ positioned $3.3 \AA$ from the reactive $\mathrm{NH}^{1}$ of substrate arginine. This cysteine controls electrophilic and nucleophilic character of the guanidinium group that is crucial for enzymatic phosphoryl transfer between ADP and ATP.
\end{abstract}

(C) 2013 Elsevier B.V. All rights reserved.

\section{Introduction}

Trypanosomes are responsible for the economically important veterinary infections and severe human diseases. In Africa, Trypanosoma brucei causes sleeping sickness also known as the African trypanosomiasis, while in America, Trypanosoma cruzi causes Chagas disease [1-3]. Infection by the $T$. brucei is fatal if untreated. It is however unfortunate that the current treatments are beset with several shortcomings including limited efficacy, unwanted toxicity and emergence of resistant strains of trypanosomes. These and other factors highlight the need for innovative strategies to combat the disease. The absence of effective anti-trypanosomal therapies coupled with unsuccessful efforts at vaccine development occasioned by the phenomenon of antigenic variation has stimulated the numerous research investigations directed at understanding the molecular biology and biochemistry of trypanosomes. Among the biomedical target molecules which have been identified as possible drug targets in trypanosomatids is arginine kinase (AK), a phosphotransferase enzyme responsible for the reversible formation of phosphoarginine using L-arginine and ATP as substrates (Fig. 1) [4]. Phospho-arginine can act as an emergency reservoir, not only of ATP but also for inorganic phosphate [5-7].

\footnotetext{
* Corresponding author at: Department of Biochemistry, Microbiology and Biotechnology, Rhodes University, P.O. Box 94, Grahamstown 6140, South Africa. Tel.: +27 46 6038085; fax: +27 466223984.

E-mail address: C.Whiteley@ru.ac.za (C.G. Whiteley).
}

The enzyme AK is absent in humans [8], a fact that makes it an attractive target choice for trypanocide development. These researchers demonstrated an increased activity of AK in trypanosomes when linked to oxidative stress and its inhibition, in any way possible, would be lethal to the parasite supporting the importance of AK to the survival of the trypanosomes. During the parasite life-cycle the trypanosomes are constantly exposed to the pro-oxidants in the blood of mammalian host, and consequently either the absence of AK or its decrease in activity would present serious consequences to the growth and survival of the parasites. In light of this, compounds that selectively inhibit AK are desirable and should become candidates for early development of trypanocides.

Metal nanoparticles, especially silver and gold, with their increased solubility, have been reported to possess interesting properties including anti-microbial activity [9,10], and to cause changes in enzyme activities [11-13].

Engineering nanoparticles that are capable of selective binding to enzymes, is a new research direction with exciting prospects in biomedical applications and there are two fundamental approaches used - either a direct covalent or non-covalent link [14,15]. In the former, there is multiple non-specific binding of the nanoparticle to cysteine side chains leading to a loss of enzyme activity, usually with conformational changes to protein structure. With the second, non-covalent method, either 'naked' or fully functionalised nanoparticles interact with enzymes under normal protein-protein interactions through the evolution of a loosely attached protein 'corona' around the nanoparticles. The 'naked' nanoparticles tend to irreversibly bind and deform an initial layer of biomolecules that 


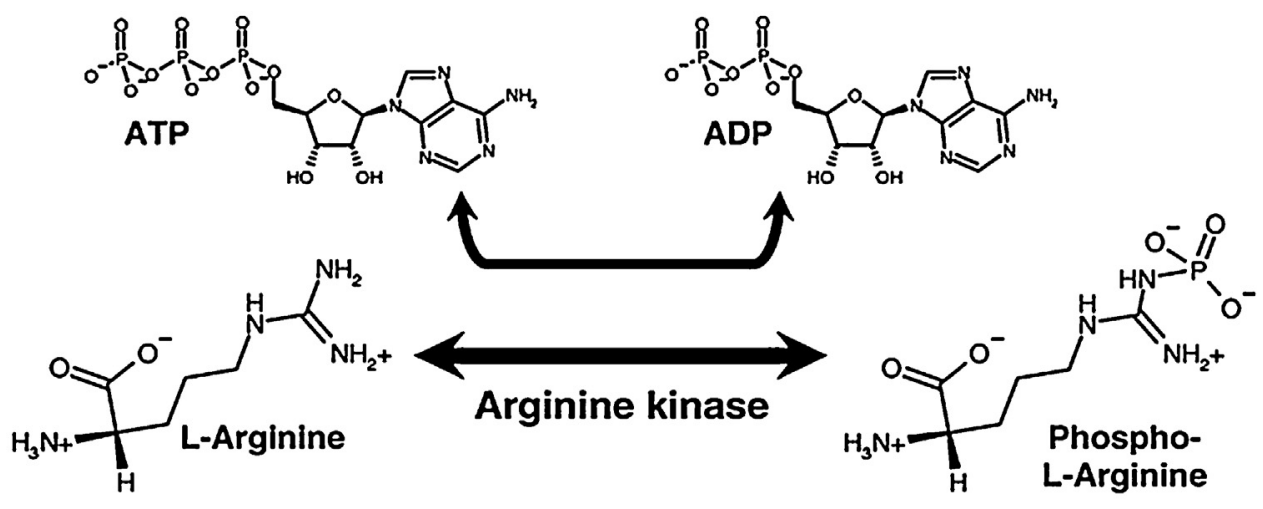

Fig. 1. Enzymatic reaction for arginine kinase.

form the first 'corona' layer, while functionalised nanoparticles, which already have an irreversible bound initial layer, act similarly by binding available biomolecules [14-16]. The binding between nanoparticles and the enzyme changes the structure of the latter and as the particle gets smaller not only does its interaction with the protein change but the composition of the protein itself changes. Consequently the 'nanoparticle-enzyme corona' has totally different biological properties in comparison to a native enzyme.

The nanoscale size of these metal nanoparticles allows their unique and remarkable properties to be exploited within the nanomedical fraternity [17-21] and to resolve several medical challenges in both infectious (malaria) and neurodegenerative diseases (Alzheimer). It is against this backdrop that the present study sought to investigate the interaction of silver and/or gold nanoparticles with a recombinant form of AK obtained from T. brucei (TbAK).

\section{Materials and methods}

\subsection{Materials}

Genomic DNA of T. brucei (strain: 927/4GUTat 10.1) was a gift from Professor Ullman, Department of Biochemistry \& Biophysics, Oregon Health \& Science University, Portland, Oregon, USA. Enzymes and PCR reagents were provided by Thermo Fischer Scientific, USA. A Bioflux kit was obtained from Separation Scientific (South Africa). Oligonucleotides and primers were from the Integrated DNA Technology (IDT) USA. The clone JET PCR kit, pSMART and pET-28b (+) as well as the BL21 DE3 and JM 109 strain of E. coli were obtained from Fermentas Life Sciences (USA). Absorbance spectroscopy was performed with a Synergy Mx (Monochromator Multi-Mode Microplate Reader, Biotek Instruments, Inc., USA). All other reagents were of analytical grade and obtained from Sigma, USA or from domestic suppliers unless otherwise stated.

\subsection{Cloning of TbAK from genomic DNA [22]}

The specific primers of TbAK including the forward (CAT ATG GGC TTC GGA TCA TCA AAA CCC) with NdeI restriction site underlined and reverse (CTC GAG CTG TTC CAC GTA CCT GC) with XhoI restriction site underlined were used to amplify the ORF of the TbAK gene. The PCR reaction was carried out with amplification conditions as follows: $98^{\circ} \mathrm{C}$ at $3 \mathrm{~min}, 98^{\circ} \mathrm{C}$ at $30 \mathrm{~s}, 62^{\circ} \mathrm{C}$ for $30 \mathrm{~s}$, $72{ }^{\circ} \mathrm{C}$ for $1 \mathrm{~min}, 72^{\circ} \mathrm{C}$, and held at $4{ }^{\circ} \mathrm{C}$ in a Biorad T100 thermal cycler. The 1000 bp product by PCR, excised and gel purified using a Bioflux kit was phosphorylated and blunt ligated into a pSMART vector using a T4 DNA ligase and then transformed into JM 109 cells. The plasmid containing TbAK was gel purified using the Bioflux kit and sequenced. This product showed 100\% identity with the Trypanosoma brucei expressed product (Accession number - XP_826998.1) and a high identity with other related guanidino kinases. The plasmid was double digested and a fragment between NdeI and Xhol restriction sites containing the TbAK gene was excised from the plasmid and subcloned into pET-28b (+) expression vector previously treated with NdeI and Xhol. This plasmid transcribes under the control of $\mathrm{T} 7$ promoter and includes a polyhistidine tag.

\subsection{Expression and purification of $T b A K$}

A method previously described [23] was adopted with slight modification. The recombinant plasmid pET-28b (+) containing the TbAK gene was transformed into BL21 DE3 cells. The transformed cells were grown overnight, at $37^{\circ} \mathrm{C}$, in $50 \mathrm{ml} \mathrm{LB}$ culture medium containing kanamycin after which an aliquot $(5.0 \mathrm{ml})$ was transferred into a $2 \mathrm{~L}$ flask containing auto-media culture $(500 \mathrm{ml})$. This was grown at $20^{\circ} \mathrm{C}$, at $150 \mathrm{rpm}$ for $36 \mathrm{~h}$. Cells were then harvested $(6000 \times g, 10 \mathrm{~min})$ washed twice with Tris buffered saline (Tris- $\mathrm{HCl}, 50 \mathrm{mM} ; \mathrm{NaCl}, 150 \mathrm{mM} ; \mathrm{pH} 7.5$ ) and lysed (freeze-thawed $\left[-80^{\circ} \mathrm{C} / 4^{\circ} \mathrm{C} ; 2\right.$ cycles]) in lysis buffer $\left[\mathrm{NaH}_{2} \mathrm{PO}_{4}\right.$ buffer $(50 \mathrm{mM}, \mathrm{pH} 7.6)$ containing $\mathrm{NaCl}(300 \mathrm{mM})$, glycerol $(10 \%)$, Tween $(0.25 \%)$, imidazole $(10 \mathrm{mM})$, mercaptoethanol $(10 \mathrm{mM})$, phenylmethylsulphonylfluoride $(1 \mathrm{mM})]$. The lysed cells were centrifuged $(2700 \times \mathrm{g}, 30 \mathrm{~min})$ and the supernatant centrifuged further $(100,000 \times g, 90 \mathrm{~min})$ after which the supernatant $(150 \mathrm{ml})$ was loaded onto a Ni-nitrilotriacetic acid affinity column. The column was washed with the same lysis buffer until a steady zero-baseline was obtained and then the fusion protein was eluted with increasing amounts of imidazole $(0-500 \mathrm{mM})$ in Hepes buffer $(10 \mathrm{mM}$, $\mathrm{pH}$ 7.5). The eluted protein was concentrated using vivaspin (GE Healthcare, Sweden) and the concentrated protein further purified by FPLC on a Superdex 200 HR 10/30 with Hepes buffer ( $25 \mathrm{mM}$, $\mathrm{pH} 7.6)$ containing glycerol (15\%), EDTA (0.1 M), and KCL (1 M) at a flow rate $\left(1 \mathrm{ml} \mathrm{min}^{-1}\right)$. Proteins were resolved by SDS-PAGE in order to confirm purity of fractions before pooling. All purification procedures were carried out at $4{ }^{\circ} \mathrm{C}$.

\subsection{SDS-PAGE}

The effectiveness of the purification process was determined by SDS-PAGE [24] on samples exhibiting TbAK activity. Samples from each purification step $(20 \mu \mathrm{l})$ and a standard molecular weight marker $(10-170 \mathrm{kDa})$ were electrophoresed on $12 \%$ SDS-PAGE at 200 V. The gels were stained with Coomassie Brilliant Blue R-250, then destained in methanol:acetic acid:water $(3: 1: 6 \mathrm{v} / \mathrm{v} / \mathrm{v})$. The molecular weight of the partially purified TbAK was determined using a standard curve of log molecular weight versus distance migrated. 


\subsection{Kinetic, $p H$, temperature and stability profiles}

The activity of TbAK was assayed using a published protocol [25] with slight modification. Briefly, enzyme extract $(20 \mu \mathrm{l})$ was incubated $\left(5 \mathrm{~min}, 30^{\circ} \mathrm{C}\right)$ with $\mathrm{L}$-arginine $(10 \mathrm{mM})$, ATP $(5 \mathrm{mM})$, mercaptoethanol $(10 \mathrm{mM}), \mathrm{MgSO}_{4}(200 \mathrm{mM})$ in Tris-HCl buffer $(100 \mathrm{mM}, \mathrm{pH} 8.6)$ in a final volume of $170 \mu \mathrm{l}$. The reaction was stopped by the addition of trichloroacetic acid ( $180 \mu \mathrm{l}, 2.5 \%)$, heated $\left(100^{\circ} \mathrm{C}, 2 \mathrm{~min}\right)$ then allowed to cool. This mixture was treated with ascorbic acid/ammonium molybdate $(9 \%, 100 \mu \mathrm{l})$, left for colour development $(5 \mathrm{~min})$, and the absorbance read at $700 \mathrm{~nm}$. The kinetic properties $\left(K_{m}\right.$ and $\left.V_{\max }\right)$ were determined by varying the substrates of either arginine $(0.5-5 \mathrm{mM}$ ) (fixed ATP concentration $-5 \mathrm{mM}$ ) or ATP (1-5 mM) (fixed arginine concentration - $10 \mathrm{mM}$ ) and determining the activity of TbAK at each substrate concentration. One unit of TbAK activity is the amount of enzyme that catalyses the formation of $1 \mu \mathrm{mol}$ inorganic phosphate per minute per ml.

To determine the $\mathrm{pH}$ optimum, the enzyme extract $(20 \mu \mathrm{l})$ was assayed in different buffers [sodium acetate ( $\mathrm{pH} 3-5.5,50 \mathrm{mM}$ ); Hepes ( $\mathrm{pH}$ 6-7, $50 \mathrm{mM}$ ); Tris-HCl buffer ( $\mathrm{pH} 7.5-10,50 \mathrm{mM})]$ under the standard assay conditions. The temperature optimum of the partially purified enzyme was determined in Tris- $\mathrm{HCl}$ buffer $(\mathrm{pH}$ $7.6,50 \mathrm{mM}$ ) over a range of $20-70^{\circ} \mathrm{C}$. The reaction was started by addition of enzyme suspension $(20 \mu \mathrm{l})$ at the different temperatures. The temperature stability of TbAK was determined at the optimum temperature and $\mathrm{pH}$ and the enzyme activity at time zero was considered to be $100 \%$ relative activity and aliquots $(20 \mu \mathrm{l})$ were removed at $15 \mathrm{~min}$ intervals and analysed for activity for a maximum period of $4 \mathrm{~h}$.

\subsection{Protein determination}

The protein concentration for all experiments was routinely determined, in triplicate, according to published procedures [26]. In a 96-well titre plate was placed extract $(5 \mu \mathrm{l})$ followed by Bradford reagent $(245 \mu \mathrm{l})$. The mixture was incubated $\left(22^{\circ} \mathrm{C}, 10 \mathrm{~min}\right)$, the absorbance of the solution measured at $595 \mathrm{~nm}$ and the concentration of the unknown sample was determined using a BSA standard curve.

\subsection{Gold and silver nanoparticles}

\subsubsection{Synthesis}

The silver/gold nanoparticles (Ag/Au-Nps) were synthesised based on established protocols $[27,28]$. Either $\mathrm{AgNO}_{3}(5 \mathrm{ml}$, $100 \mathrm{mM}$ ) or $\mathrm{AuCl}_{3}(5 \mathrm{ml}, 50 \mathrm{mM})$ was added to tannic acid [20 ml, $1 \%(\mathrm{w} / \mathrm{v})$ ] with stirring followed by polyvinylpyrrolidone $(0.2 \mathrm{~g})$ and then an adjustment of $\mathrm{pH}$ to 8.0 by potassium carbonate $(150 \mathrm{mM})$. The solution turned pale yellow (Ag-NPs) or wine red (Au-NPs). The Ag/Au-Nps were filtered using the $0.22 \mu \mathrm{M}$ filter and characterised by UV/vis spectrophotometry (Biotek Epoch, USA), inductively coupled plasma optical emission spectrometry (ICP-OES, Cambridge, United Kingdom), energy dispersive X-ray spectroscopy (EDX) and transmission electron microscopy (TEM, Brno, Czech Republic).

\subsubsection{Characterisation}

2.7.2.1. UV/vis spectroscopy. UV/vis absorption spectra $(250-700 \mathrm{~nm})$ of the nanoparticles were obtained to evaluate the plasmon bands associated with the silver and/or gold nanoparticles.

2.7.2.2. Inductively coupled plasma optical emission spectroscopy (ICP OES). Nanoparticles $(250 \mu \mathrm{l})$ were dissolved in aqua regia [1:3 nitric to hydrochloric acid, $350 \mu \mathrm{l}(\mathrm{Au}) ; 500 \mu \mathrm{l}(\mathrm{Ag})]$ and digested with hydrogen peroxide $\left(1.0 \mathrm{ml}, 60^{\circ} \mathrm{C}, 1 \mathrm{~h}\right)$. Metal quantification was carried out using an inductively coupled optical emission spectrophotometer after suitable standard curves were constructed with varying concentrations of respective metal salt standards (Sigma Aldrich).

2.7.2.3. Transmission electron microscopy (TEM). Samples for TEM analysis were prepared by placing a drop of the nanoparticle sample onto carbon coated copper grids, removing excess sample after a minute using blotting paper and the grids air-dried before analysis. Duplicate samples were prepared and negatively stained using 1\% uranyl acetate. Mean particle size and standard deviations were determined by the analysis of 200 particles using the computer software "Scandium".

2.7.2.4. Energy dispersive X-ray spectroscopy (EDX). Freeze dried samples were placed on graphite tape which was in turn placed on an aluminium stub. Elemental analysis was performed with a TESCAN SEM with an EDX scanner (INCAPentalFeTx3, Oxford Instruments) operating at $20 \mathrm{keV}$.

\subsection{Kinetic analysis of interaction of $\mathrm{Ag} / \mathrm{Au}$ nanoparticles with TbAK}

The analysis was performed in the same way as that described above for TbAK activity with the same variation in substrate of either arginine $(0.5-5 \mathrm{mM}$ ) (fixed ATP concentration $-5 \mathrm{mM}$ ) or ATP (1-5 mM) (fixed arginine concentration - $10 \mathrm{mM}$ ) and either silver or gold nanoparticles $(0 \mathrm{nM} ; 2 \mathrm{nM} ; 5 \mathrm{nM})$ in a total volume of $170 \mu \mathrm{l}$. The TbAK activity was assayed, over a $5 \mathrm{~min}$ period, at each substrate concentration.

\subsection{Statistical analyses}

All analyses were carried out in triplicate and values reported as the means with standard deviation, $p<0.05$ versus controls. Where necessary analysis of variance was conducted using Statistica for Windows, version 8 (Statsoft Inc.) and Microsoft Excel 2010.

\section{Results}

\subsection{Cloning of TbAK gene}

Following specific amplification of the TbAK gene from using specific primers, a PCR product of approximately $1000 \mathrm{bp}$ was obtained. Subsequently, the nucleotide sequencing result revealed absence of mutation and a $100 \%$ identity to the Trypanosoma brucei expressed sequence (Accession number - XP_826998.1).

Table 1

Protein purification table for TbAK.

\begin{tabular}{|c|c|c|c|c|c|c|c|c|}
\hline Fraction & Vol. (ml) & $\begin{array}{l}\text { Protein } \\
\left(\mathrm{mg} \mathrm{ml}^{-1}\right)\end{array}$ & $\begin{array}{l}\text { Total protein } \\
(\mathrm{mg})\end{array}$ & $\begin{array}{l}\text { Activity } \\
\left(\mathrm{Umll}^{-1}\right)\end{array}$ & $\begin{array}{l}\text { Total } \\
\text { activity (U) }\end{array}$ & $\begin{array}{l}\text { Specific activity } \\
\left(\mathrm{Umg}^{-1}\right)\end{array}$ & Fold purity & \% Yield \\
\hline Crude & 200 & 2.29 & 458 & 2.02 & 404.0 & 0.88 & 1.0 & 100 \\
\hline Ni-affinity chromatography & 150 & 0.45 & 67.5 & 0.88 & 132 & 1.96 & 1.72 & 32.7 \\
\hline FPLCSuperdex $200 \mathrm{HR}$ & 30 & 0.22 & 6.6 & 0.64 & 19.2 & 2.92 & 3.32 & 4.8 \\
\hline
\end{tabular}




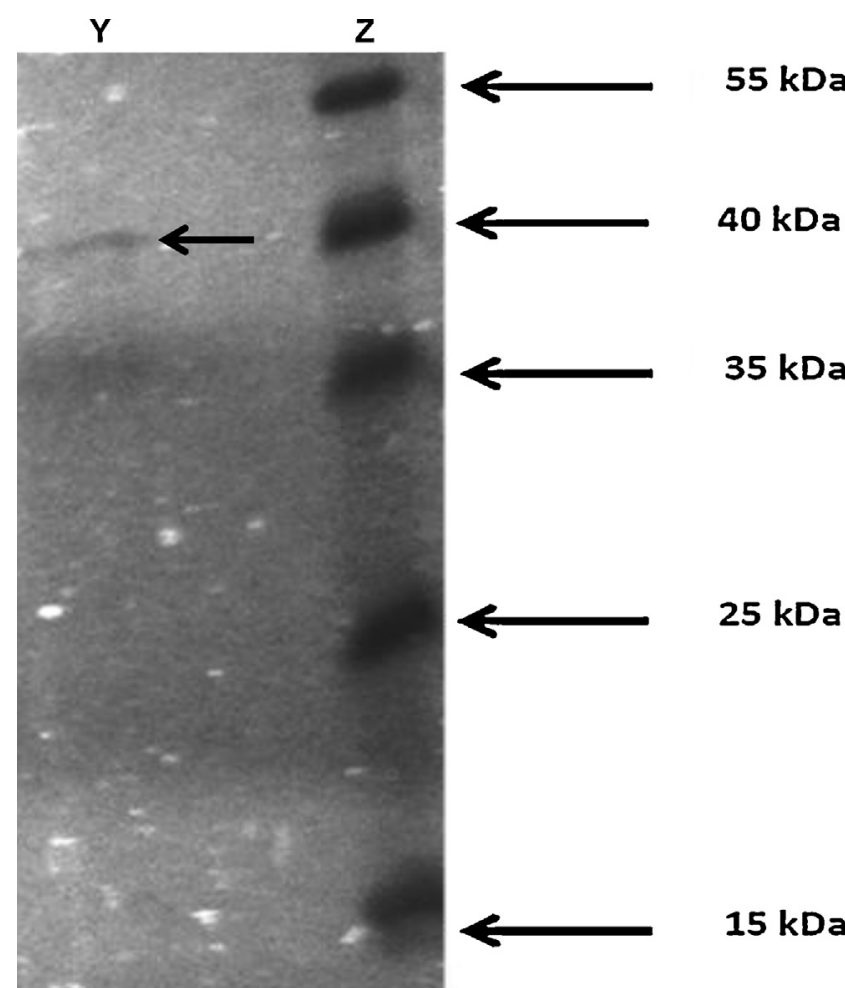

Fig. 2. SDS-PAGE for TbAK: lane $Y$ is fraction collected following purification of the His-tag eluate on a Superdex 200 HR 10/30 fast protein liquid chromatography (FPLC) system; lane Z represents the protein marker. Arrow within the gel represents the purified TBAK.

\subsection{Expression and purification of TbAK}

The recombinant TbAK gene was expressed in E. coli BL21 DE3 harbouring the vector pET-28b (+)_TbAK. Approximately $9.45 \mathrm{~g}$ of cells were harvested from $2 \mathrm{~L}$ of auto-media, lysed and purified on $\mathrm{Ni}$-nitriloacetic acid affinity column. This was further purified on a Superdex 200 HR 10/30 FPLC column yielding a near homogeneous protein in a final yield of only $4.8 \%$ (Table 1 ). The molecular weight of the fusion protein was estimated to be around $40 \mathrm{kD}$ as revealed on SDS-PAGE (Fig. 2). The specific activity of the recombinant TbAK was $2.92 \mu \mathrm{mol} \mathrm{min}{ }^{-1} \mathrm{mg}$ protein ${ }^{-1}$. The optimum temperature and $\mathrm{pH}$ for the recombinant TbAK are $30^{\circ} \mathrm{C}$ and 7.8 , respectively (data not shown).

\subsection{Silver/gold nanoparticles: synthesis and characterisation}

The UV/vis spectrophotometry with maximal absorbance wavelength at 420 and $540 \mathrm{~nm}$, respectively, indicated the plasmon resonance absorbance of the $\mathrm{Ag} / \mathrm{Au}$ nanoparticles [27,28] (Fig. 3). The TEM analysis of the synthesised nanoparticles revealed them to be spherical in shapes with sizes ranging from 4 to $9 \mathrm{~nm}$ and 7 to $22 \mathrm{~nm}$, respectively, for $\mathrm{Ag}$ and Au nanoparticles (Fig. 3). After ICP-OES analysis the concentration of the metal nanoparticles was 30.8 and $76.6 \mu \mathrm{M}$ for $\mathrm{Ag}$ and $\mathrm{Au}$ nanoparticles, respectively.

\subsection{Kinetic analysis}

A study into the effect of substrate concentration on the kinetic activity of TbAK was investigated by measuring enzyme activity over a range of arginine concentrations $(0-5 \mathrm{mM})$. A typical increase in substrate concentration resulted in a proportional increase in
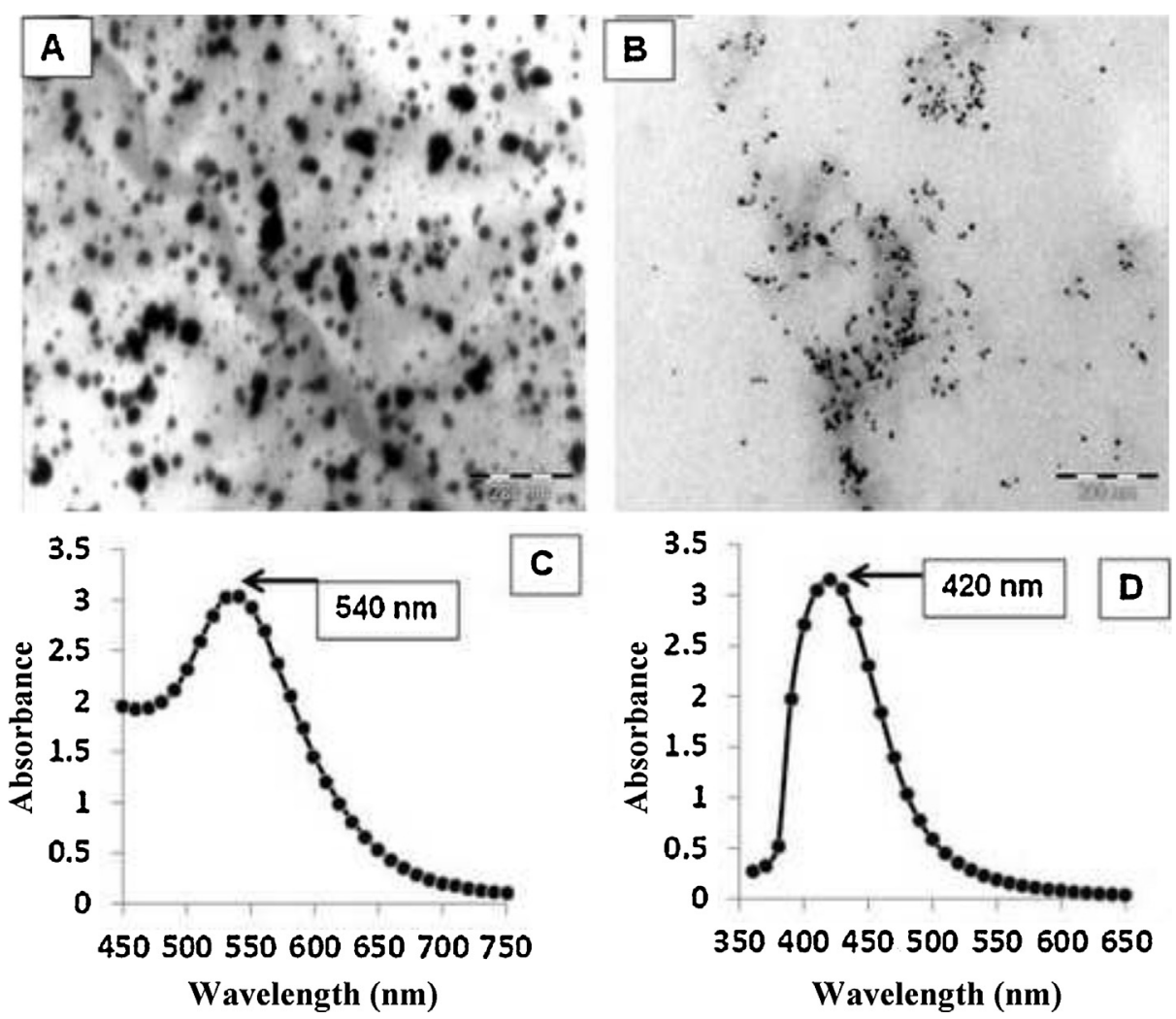

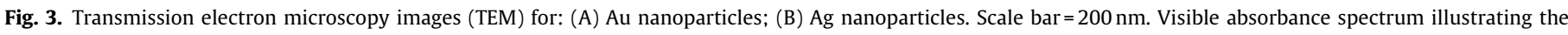
plasmon resonance band for: (C) Au nanoparticles (540 nm); (D) Ag nanoparticles (420 nm). 
(a)
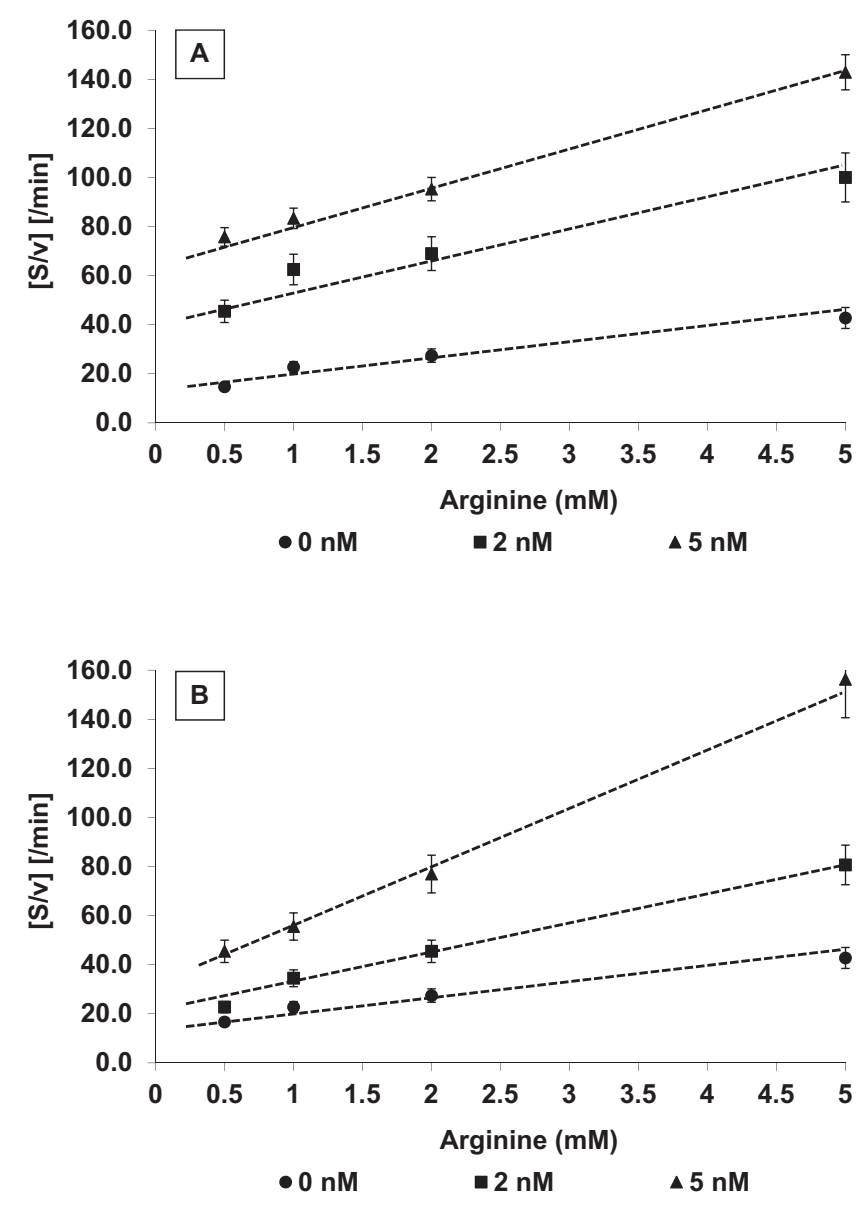

(b)
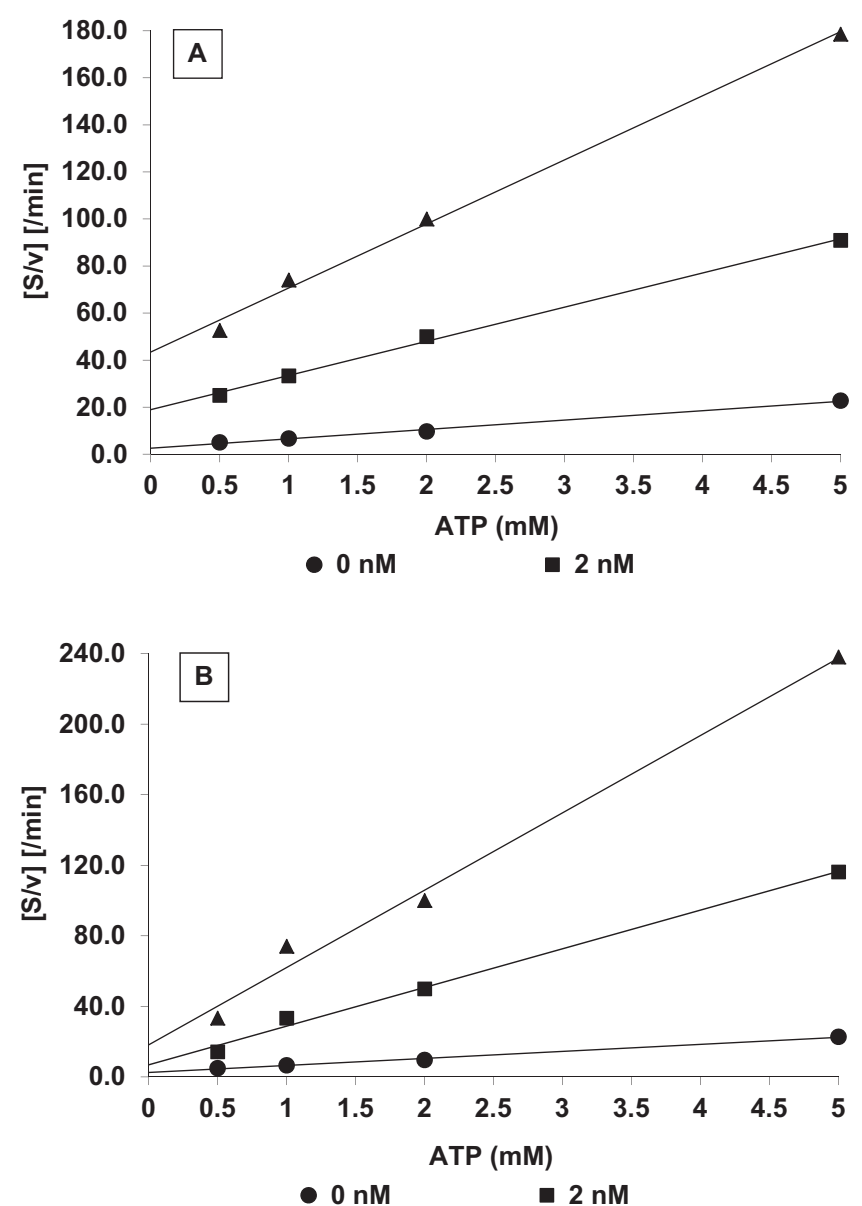

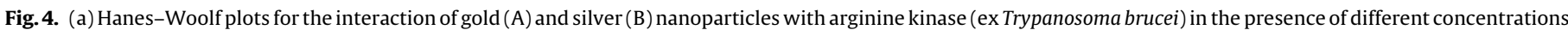

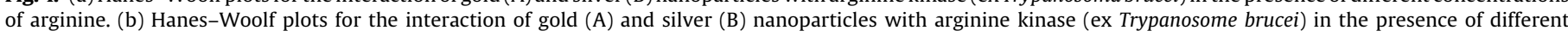
concentrations of ATP.

activity as shown by the Hanes-Woolf plot (Fig. 4) and with arginine as substrate, the $V_{\max }$ and $K_{m}$ were $0.161 \mu \mathrm{mol} \mathrm{ml}^{-1} \mathrm{~min}^{-1}$ and $2.94 \mathrm{mM}$, respectively. With a total amount of enzyme of $340 \mathrm{nmol}$ the turnover number $\left(k_{\text {cat }}\right)$ and the catalytic efficiency were calculated using Eqs. (1) and (2) and were found to be $0.0079 \mathrm{~s}^{-1}$ and $2.68 \times 10^{-6} \mathrm{~s}^{-1} \mu \mathrm{M}^{-1}$, respectively.

$k_{\text {cat }}=\frac{V_{\max }}{E_{t}}$

Catalytic efficiency $=\frac{k_{\text {cat }}}{K_{m}}$

The interaction of the silver and gold nanoparticles with TbAK was determined by including the particles at a concentration of 2 and $5 \mathrm{nM}$ with either arginine, between 0.5 and $5 \mathrm{mM}$ concentration at fixed levels of ATP $(5 \mathrm{mM})$, or ATP, between 1 and $5 \mathrm{mM}$ concentration at fixed levels of arginine $(10 \mathrm{mM})$. The results indicated that with respect to arginine as a variable substrate, for each type of particle the $V_{\max }$ decreased (Fig. 4a), while the $K_{m}$ virtually remained unchanged. At $5 \mathrm{nM} \mathrm{Au}$ nanoparticle the $V_{\max }$ decreased from $0.161 \mu \mathrm{mol} \mathrm{min}^{-1} \mathrm{ml}^{-1}$ to $0.067 \mu \mathrm{mol} \mathrm{min}{ }^{-1} \mathrm{ml}^{-1}$ - a $62 \%$ decrease. At $2 \mathrm{nM}$ Au nanoparticle the $V_{\max }$ app was $0.082 .5 \mu \mathrm{mol} \mathrm{min}{ }^{-1} \mathrm{ml}^{-1}$ - an approximate decrease of enzyme activity of $50 \%$. The decrease is more effective with $\mathrm{Ag}$ nanoparticle. At $5 \mathrm{nM} \mathrm{Ag}$ nanoparticle the $V_{\max }$ decreased from $0.161 \mu \mathrm{mol} \mathrm{min}^{-1} \mathrm{ml}^{-1}$ to $0.041 \mu \mathrm{mol} \mathrm{min}^{-1} \mathrm{ml}^{-1}$ - a $75 \%$ decrease. At $2 \mathrm{nM} \mathrm{Ag}$ nanoparticle the $V_{\max }{ }^{\text {app }}$ was $0.078 \mu \mathrm{mol} \mathrm{min}{ }^{-1} \mathrm{ml}^{-1}$ - an approximate decrease of enzyme activity of $48 \%$. The inhibitor constant $\left(K_{\mathrm{i}}\right)$ calculated from Eq. (3) indicated the binding affinity of TbAK for the nanoparticles.

$K_{i}=\frac{\left[\mathrm{np} \cdot V_{\max }^{\mathrm{app}}\right]}{\left[V_{\max }-V_{\max }^{\mathrm{app}}\right]}$

where $\mathrm{np}$ is the concentration of nanoparticle; $V_{\max }$ app is the apparent maximum velocity in the presence of nanoparticle. Results indicated that Ag nanoparticles inhibited TbAK the most as reflected by its relatively low $K_{\mathrm{i}}$ value of $1.59 \mathrm{nM}$; $K_{\mathrm{i}}$ values for Au nanoparticle was estimated at $3.1 \mathrm{nM}$.

With ATP as the variable substrate (Fig. 4b) $V_{\max }$ and $K_{m}$ are $0.208 \mu \mathrm{mol} \mathrm{min}^{-1} \mathrm{ml}^{-1}$ and $0.06 \mathrm{mM}$, respectively, and there was over $90 \%$ inhibition of the enzyme with $\mathrm{Ag}$ nanoparticles (Fig. 5) and close to $95 \%$ inhibition with Au nanoparticle; respective $K_{\mathrm{i}}$ values are $4.7 \mathrm{nM}$ and $7.2 \mathrm{nM}$.

\section{Discussion}

Since arginine kinase from $T$. brucei is absent in mammalian hosts [8] yet is critical for trypanosome survival under stressful conditions it was clear that studies targeted at selective inhibition of TbAK had high clinical implications in combating the disease. 


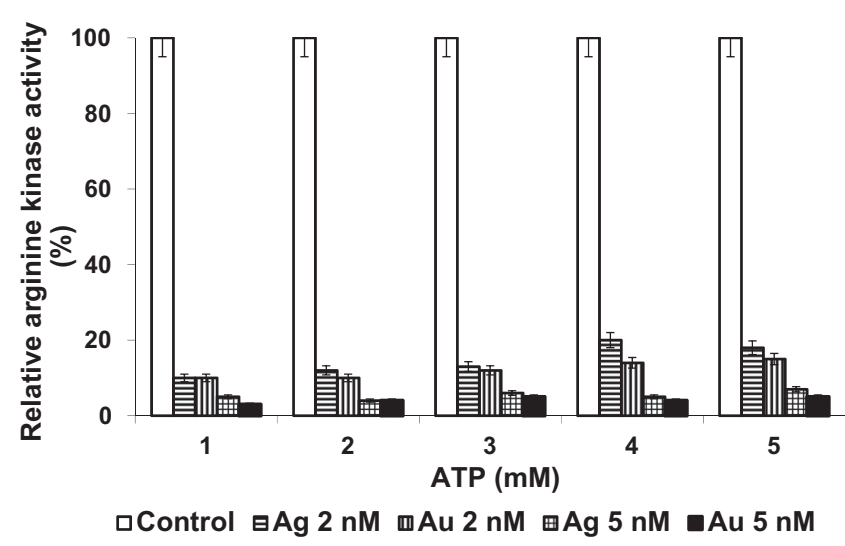

Fig. 5. Relative activity of TbAK with ATP as the substrate and in the presence of varying amounts of $\mathrm{Ag}$ and Au nanoparticles. Control represents $100 \%$ activity $\left[0.208 \mu \mathrm{mol} \mathrm{min}^{-1} \mathrm{ml}^{-1}\right]$.

The current study has investigated the interaction between metal nanoparticles ( $\mathrm{Ag}$ and $\mathrm{Au}$ ) and TbAK and evidence presented shows decreased enzyme activity by $75-50 \%$. For the case of Au nanoparticles the maximum decrease in $V_{\max }$ was $62 \%$ (from $0.161 \mu \mathrm{mol} \mathrm{min}{ }^{-1} \mathrm{ml}^{-1}$ to $0.067 \mu \mathrm{mol} \mathrm{min}^{-1} \mathrm{ml}^{-1}$ ) while with $\mathrm{Ag}$ nanoparticles this decrease was over $75 \%$ (from $0.161 \mu \mathrm{mol} \mathrm{min}{ }^{-1} \mathrm{ml}^{-1}$ to $0.041 \mu \mathrm{mol} \mathrm{min}^{-1} \mathrm{ml}^{-1}$ ). With $K_{m}$ values remaining fairly constant it pointed towards a non-competitive inhibition with respect to both arginine and ATP substrates suggesting the particles bind to sites on the enzyme other than the active sites.

Although a thorough computational molecular docking of the $\mathrm{Ag} / \mathrm{Au}$ nanoparticles with TbAK is currently being undertaken and will be reported elsewhere, the mechanism of binding and interaction is as yet unclear. Earlier studies by our group has inferred that such nanoparticles have strong affinity to the thiol (-SH) group of cysteine residues in enzymes and were responsible for the change in enzyme conformation and change in activity [12,13,20,21]. Though it may be regarded as being speculative we offer a possible mechanism.

As far as we were aware no crystallographic structure for arginine kinase from $T$ brucei had been deposited in the Protein Data Bank. On the other hand that for T. cruzi (TcAK) had been reported

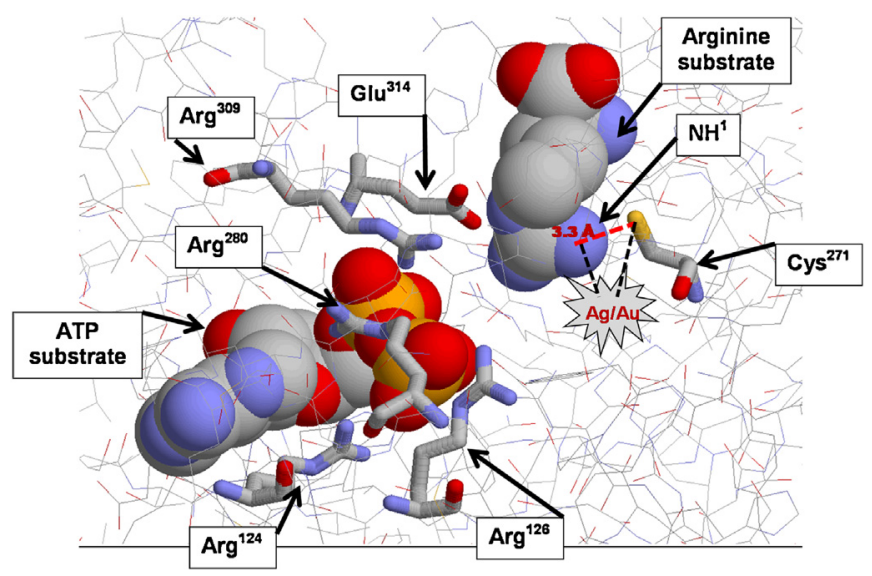

Fig. 6. Tentative mechanism for the interaction of silver/gold nanoparticle with arginine kinase from Trypanosoma cruzi TcAK [PDB ID: 2J1Q] through Cys ${ }^{271}$, interfering with $N_{1}$ of the arginine substrate. The four arginine residues ( $\operatorname{Arg}^{124}, \operatorname{Arg}^{126}, \operatorname{Arg}^{280}$, and $\mathrm{Arg}^{309}$ ) and $\mathrm{Glu}^{314}$ are all involved to enhance the enzymatic rate through the alignment of substrate [31]. The interatomic distance between the thiolate atom of $\mathrm{Cys}^{271}$ and $\mathrm{NH}^{1}$ of the arginine substrate is $3.3 \AA$. Nitrate not shown.
[29] with $82 \%$ analogy [2] to T. brucei. The analysis of the primary structure of TCAK (PDB ID: 2J1Q) reveals that the active site for TbAK consists of four arginine residues ( $\operatorname{Arg}^{124}, \operatorname{Arg}^{126}, \operatorname{Arg}^{280}$, and $\mathrm{Arg}^{309}$ ) and a glutamic acid residue ( $\mathrm{Glu}^{314}$ ) all of which enhance the enzymatic rate through the alignment of substrate [30]. Contrary to this work, however, it is seen that the thiolate sulphur atom from $\mathrm{Cys}^{271}$ is $3.3 \AA$ from the reactive $\mathrm{NH}^{1}$ of the arginine substrate and 4.82 Å from the unreactive $\mathrm{N}_{\varepsilon}$ (Fig. 6); it is the $\mathrm{NH}^{1}$ that becomes covalently phosphorylated. These workers imply that $\mathrm{Cys}^{271}$ is not absolutely essential for TbAK catalysis and does not participate in a substrate-induced conformational change of the enzyme [29]. It is possible [31] that the electronegative thiolate would induce overall positive charge to the reactive $\mathrm{NH}^{1}$ of the arginine substrate disrupting the resonance of the guanidinium group and increasing the nucleophilicity of this reactive $\mathrm{NH}^{1}$ towards attack on the $\gamma$-phosphoryl group of ATP. With the ATP forming reaction (reverse scenario) a proton disposition from the guanidinium group towards the thiolate should enhance any phosphoryl transfer to ADP. Our suggestion that $\mathrm{Ag} / \mathrm{Au}$ nanoparticles interact with this thiolate atom supports our findings for inhibition of the enzyme and that since the cysteine is not directly involved at the active site lends credence for a non-competitive mechanism for inhibition.

Reiterating, at this stage that it may be considered speculation to propose a tentative mechanism it is probable that the following scenarios may occur. Not only do the noble metallic nanoparticles, especially Au and Ag, have catalytic properties [32,33] but it is a well known fact that they have a high propensity for sulphur. Consequently, based upon other findings from our laboratories [20,21], the Au/Ag nanoparticles would then associate with the sulphur atom of $\mathrm{Cys}^{271}$ decreasing its electronegativity. At the same time, since the $\mathrm{NH}^{1}$ of the arginine substrate is only $3.3 \AA$ away from this cysteine, there would be disruption of resonance of the guanidinium group and an enhancement of proton migration. This would, in turn, decrease the nucleophilicity of the $\mathrm{NH}^{1}$ towards attack on the $\gamma$-phosphoryl group of ATP. For the enzymatic formation of ATP, a blocking of the Cys ${ }^{271}$ thiolate by nanoparticles would prevent its acceptance of a proton from the guanidinium group decreasing the overall phosphoryl transfer to ADP.

\section{Conclusion}

To our knowledge, this is the first report demonstrating the inhibitory potentials by the $\mathrm{Ag} / \mathrm{Au}$ nanoparticles on the activity of TbAK with $K_{\mathrm{i}}$ values in the nM range: $1.59 \mathrm{nM}(\mathrm{Ag}) ; 3.1 \mathrm{nM}(\mathrm{Au})$ in the presence of arginine as substrate and $4.7 \mathrm{nM}(\mathrm{Ag}) ; 7.2 \mathrm{nM}(\mathrm{Au})$ in the presence of ATP as substrate. Overall the decrease in enzyme activity was $75 \%$ in the presence of $\mathrm{Ag}$ nanoparticles and $62 \%$ with Au nanoparticles. The mechanism of inhibition was consistent with non-competitive interactions with either, or both substrates (ATP; arginine). $\mathrm{Cys}^{271}$ is juxtapositioned $3.3 \AA$ from the reactive $\mathrm{NH}^{1}$ of the substrate arginine and we propose that in line with other reported evidence, when the nanoparticles interact with the thiolate group of $\mathrm{Cys}^{271}$ they disrupt, not only its electronegativity but also the resonance of the guanidinium group decreasing nucleophilic potential of the $\mathrm{NH}^{1}$ towards attack on the $\gamma$-phosphoryl group. Any interference of the thiolate by nanoparticles would also prevent proton transfer from the guanidinium group decreasing the overall phosphoryl transfer to ADP.

\section{Conflict of interest}

None. 


\section{Acknowledgements}

The authors wish to thank the National Research Foundation, South Africa and to Rhodes University, South Africa for financial assistance. We thank Professor Ullman (Department of Biochemistry \& Biophysics, Oregon Health \& Sciences University, USA) for the gift of genomic DNA of T. Brucei (strain: 927/4GUTat 10.1) and Dr. J. van Marjwik (Department of Biochemistry, Microbiology \& Biotechnology, Rhodes University, Grahamstown, South Africa), for valuable advice and assistance.

\section{References}

[1] H.B. Tanowitz, L.V. Kirchhoff, D. Simon, S.A. Morris, L.M. Weiss, M. Wittner, Clin. Microbiol. Rev. 5 (4) (1992) 400-419.

[2] C.A. Pereira, G.D. Alonso, H.N. Torres, M.M. Flawiá, J. Euk. Microbiol. 49 (2002) $82-85$

[3] K.M. Tyler, D.M. Engman, Int. J. Parasitol. 31 (5-6) (2001) 472-481.

[4] C.A. Pereira, G.D. Alonso, M.C. Paveto, M.M. Flawiá, H.N. Torres, J Euk. Microbiol. 46 (1999) 566-570

[5] K. Uda, N. Fujimoto, Y. Akiyama, K. Mizuta, K. Tanaka, W.R. Ellington, T. Suzuki, Comp. Biochem. Physiol. Part D: Genom. Proteom. 1 (2006) 209-218.

[6] L.D. Andrews, J. Graham, M.J. Snider, D. Fraga, Comp. Biochem. Physiol. Part B: Biochem. Mol. Biol. 150 (2008) 312-319.

[7] C.A. Pereira, G.D. Alonso, S. Ivaldi, A.M. Silber, M.J. Alves, H.N. Torres, M.M. Flawiá, FEBS. Lett. 554 (2003) 201-205.

[8] M.R. Miranda, G.E. Canepa, L.A. Bouvier, C.A. Pereira, Exp. Parasitol. 114 (2006) $341-344$.

[9] D. MubarakAli, N. Thajuddin, K. Jeganathan, M. Gunasekaran, Colloid Surf. B: Biointerface 85 (2011) 360-365.

[10] N.C.J. Lekshmi, S.B. Sumi, S. Viveka, S. Jeeva, J.R. Brindha, Microbiol. Biotech. Res. 2 (2012) 115-119.

[11] N.S. Wigginton, A. Titta, F. Piccapietra, J. Dobias, V.J. Nesatyy, M.J.F. Suter, B. Bernier-Latmani, Environ. Sci. Technol. 44 (2010) 2163-2168.
[12] A.A. Salma, H.A. Amer, H.A. Shaemaa, K.A. Abdulrahman, Int. J. Chem. Res. 1 (2011) 1-11.

[13] M. Srivastava, S. Singh, W.T. Self, Environ. Health Perspect. 120 (2011) 56-61.

[14] I. Lynch, K.A. Dawson, Nano Today 3 (1) (2008) 40-47.

[15] M.P. Monopoli, C. Aberg, A. Salvati, K.A. Dawson, Nat. Nanotechnol. 7 (2012) 779-786.

[16] A. Salvati, A.S. Pitek, M.P. Monopoli, K. Prapaino, F.B. Bombelli, D.R. Hristov, P.M. Kelly, C. Aberg, E. Mahon, K.A. Dawson, Nat. Nanotechnol. 2 (2013) $137-143$.

[17] E.R. Padayachee, N. Ngqwala, C.G. Whiteley, J. Enzyme Inhib. Med. Chem. 27 (2011) 356-364

[18] E.R. Padayachee, C.G. Whiteley, Biochim. Biophys. Acta 1810 (2011) 1136-1140

[19] E.R. Padayachee, C.G. Whiteley, Neuropeptides (2013), http://dx.doi.org/10. 1016/j.npep.2012.12.006.

[20] A. Sennuga, J. van Marwijk, C.G. Whiteley, Nanotechnology 23 (2012) 035102, http://dx.doi.org/10.1088/0957-4484/23/3/035102.

[21] A. Sennuga, J. van Marwijk, A. Boshoff, C.G. Whiteley, J. Nanoparticle Res. 14 (2012) 824-835, http://dx.doi.org/10.1007/s11051-012-0824-6.

[22] C.A. Pereira, G.D. Alonso, M.C. Paveto, A. Iribarren, M.L. Cabanas, H.N. Torres, M.M. Flawiá, J. Biol. Chem. 275 (2000) 1495-1501.

[23] F.W. Studier, Protein Expr. Purific. 41 (2005) 207-234.

[24] U.K. Laemmli, Nature 227 (1970) 680-685.

[25] S. Guo, Z. Guo, X. Guo, B. Chen, X. Wang, Protein Expr. Purific. 29 (2003) 230-234.

[26] M.M. Bradford, Anal. Biochem. 72 (1976) 248-254.

[27] S.K. Sivaraman, S. Kumar, V. Santhanam, Gold Bull. 43 (2010) 275-285.

[28] S.K. Sivaraman, I. Elango, S. Kumar, V. Santhanam, Curr. Sci. 97 (2009) 1055-1099.

[29] P. Fernandez, A. Haouz, C.A. Pereira, C. Aguilar, P.M. Alzari, Proteins 69 (2007) 209-214.

[30] R. Furter, E.M. Furter-Graves, T. Wallimann, Biochemistry 32 (1993) $7022-7029$.

[31] J.L. Gattis, E. Ruben, M.O. Fenley, W.R. Ellington, M.S. Chapman, Biochemistry 43 (2004) 8680-8689.

[32] C.T. Campbell, J.C. Sharp, Y.X. Yao, E.M. Karp, T.L. Silbaugh, Faraday Discuss. 152 (2011) 227-239.

[33] W. Li, C. Sun, B. Hou, X. Zhou, Int. J. Spectrosc. 2012 (2012) 1-7. 